\title{
Emphysematous abomasitis in a lamb by bacteria of the Sarcina genus in Southern Brazil
}

\author{
Abomasite enfisematosa por bactérias do gênero Sarcina em um \\ cordeiro no sul do Brasil
}

\section{Ronaldo Viana Leite Filho $^{I}$ Matheus Viezzer Bianchi ${ }^{I}$ Gabriela Fredo \\ Eduardo Conceição de Oliveira ${ }^{\mathrm{I}}$ Cláudio João Mourão Laisse ${ }^{\mathrm{I}}$ David Driemeier $^{\mathrm{I}}$ Saulo Petinatti Pavarini ${ }^{{ }^{*}}$}

ABSTRACT

Abomasal bloat associated with Sarcina genus bacteria is a rare condition reported in young ruminants. An outbreak characterized by the sudden death of eight lambs from a total of 80 lambs (30 days-old) occurred on a property located in the city of Palmares do Sul in the state of Rio Grande do Sul. Deaths began to occur after the introduction of supplementation into the diet of lambs. At necropsy, the abomasum was distended by gas and had diffusely thickened walls and emphysema. On microscopic examination, the abomasum showed marked diffuse emphysema and multifocal areas of mild superficial necrosis with many coccoid structures measuring approximately $2 \mu \mathrm{m}$ in diameter, arranged in tetrads, compatible with Sarcina genus bacteria. After removing supplementation from the diet, no more deaths occurred. The diagnosis of this case was established by gross and microscopic lesions in addition to the clinical and epidemiological findings. Therefore, it was concluded that it was an outbreak of emphysematous abomasitis by Sarcina genus bacteria in lambs.

Key words: emphysematous abomasitis, lamb, Sarcina, abomasal bloat.

\section{RESUMO}

Timpanismo abomasal associado a bactérias do gênero Sarcina é uma enfermidade relativamente rara e reportada em ruminantes jovens. Um surto com morte súbita, acometendo oito cordeiros (30 dias de idade), de um total de 80, ocorreu em uma propriedade localizada no município de Palmares do Sul, Rio Grande do Sul. As mortes começaram a ocorrer após a introdução de suplementação na dieta dos cordeiros. Um cordeiro foi necropsiado e apresentava o abomaso distendido por gás, com parede espessada e aspecto enfisematoso. No exame microscópico, o abomaso apresentou, além de enfisema difuso acentuado, áreas multifocais de discreta necrose superficial, com inúmeras estruturas cocoides, de aproximadamente $2 \mu \mathrm{m}$ de diâmetro, arranjadas em tétrades, compativeis com bactérias do gênero Sarcina. Após a remoção da suplementação da dieta, não ocorreram mais óbitos. O diagnóstico desse caso foi estabelecido a partir dos achados macroscópicos e microscópicos observados no abomaso e, devido à apresentação clínica e epidemiológica dos demais casos, concluiu-se que se tratou de um surto de abomasite enfisematosa em cordeiros por bactérias do gênero Sarcina.

Palavras-chave: abomasite enfisematosa, cordeiro, Sarcina, timpanismo abomasal.

Abomasal bloat associated with the Sarcina genus of bacteria is a rare disease reported in young ruminants such as calves (EDWARDS et al., 2008), lambs (VATN et al., 2000; EDWARDS et al., 2008) and kids (DEBEY et al., 1996). Pathogenesis of abomasal bloat is not yet fully elucidated. This syndrome has a multifactorial origin; it may be due to excess of carbohydrate fermentation in the abomasum, by the presence of gas-producing bacteria in the abomasum (such as the Sarcina, Lactobacillus or Clostridium genus) (PANCIERA et al., 2007) or due to environmental factors such as geographical area, floor type and interaction between the surface and the percentage of silage in the diet (LUTNAES \& SIMENSEN, 1983). Sarcina genus bacteria have been associated with many gastric disorders, especially in humans, young or adult, as in cases of delayed gastric emptying and gastric outlet obstruction (LAM-HIMLIN et al., 2011). The bacteria of this genus was observed in lambs with

ISetor de Patologia Veterinária, Faculdade de Veterinária, Universidade Federal do Rio Grande do Sul (UFRGS), Avenida Bento Gonçalves, 9090, Prédio 42505, 91540-000, Porto Alegre, RS, Brasil. E-mail: saulo.pavarini@ufrgs.br. "Corresponding author. 
acute dilatation of the abomasum (VATN et al., 2000; EDWARDS et al., 2008) and reported in association with abomasal bloat in calves and kids (DEBEY et al., 1996). These bacteria are distinguished by exhibiting cubical arrangement groups, often in tetrads, and occasionally in cubes formed by eight cells (CANALE-PAROLA, 1970). They are ubiquitous, coccoid, Gram-positive, obligate anaerobes and were first documented in the human gastrointestinal tract (GOODSIR, 1842). The purpose of this report is to describe the epidemiological, gross and histologic findings observed in a lamb with emphysematous abomasitis by bacteria of the Sarcina genus.

A 25 day-old Texel lamb was received for post-mortem examination. Information about the lamb was obtained from the veterinarian and the owner of the property. At necropsy, multiple organs were collected and fixed in $10 \%$ neutral buffered formalin. Subsequently, tissue samples were routinely processed, and sections were stained with hematoxylin and eosin (HE). Bacteria in the abomasum were evidenced by Periodic acid-Schiff (PAS), Grocott's methenamine silver and modified Brown-Hopps (Gram) techniques.

The lamb was from a property located in the city of Palmares do Sul $\left(30^{\circ} 15^{\prime} \mathrm{S} ; 50^{\circ} 30^{\prime} \mathrm{W}\right)$ in the state of Rio Grande do Sul. This property had a total of 150 sheep and 80 lambs (30 days-old), all farmed in a semi-intensive system on native grass. Lambs and sheep were being fed with soybeans and corn. Deaths in the lambs began to occur after the introduction of diet supplementation with protein salt, composed of ground corn, soybean meal, urea, dicalcium phosphate and carbo-amino-phosphochelate. Three days later, eight lambs suddenly died with no previous clinical signs. No adult sheep died at that time. After removal of protein salt from the diet, there were no more deaths of lambs on that property.

At the necropsy, the abomasum was markedly distended by gas with the mucosa showing white punctiform multifocal areas and large amounts of mucus. On cut surface, the abomasal wall was thickened and had an emphysematous appearance (Figure 1A). On microscopic examination, the abomasum showed marked diffuse emphysema in the submucosa, moderate emphysema in the mucosa and discrete multifocal emphysema in the muscular and serosal layers (Figure 1B). It was also observed multifocal areas of necrosis associated with numerous discrete coccoid structures approximately $2 \mu \mathrm{m}$ in diameter, individually or in groups of four or more cells adhered to the mucosa, morphologically compatible with bacteria of the Sarcina genus
(Figure1C). These bacterial structures were evidenced by PAS, Grocott's methenamine silver (Figure 1D), and Brown-Hopps staining (compatible with Grampositive bacteria) (Figure 1E).

The gross and microscopic findings observed in this case led to a diagnosis of emphysematous abomasitis due to bacteria of the Sarcina genus. The changes observed are similar to those described by other authors that reported this disease in young ruminants that presented abdominal distension, shock, pain and sudden death and, at necropsy, increased abdominal volume, as well as edema and emphysema in the abomasal wall (DEBEY et al., 1996; VATN et al., 2000; PANCIERA et al., 2007; EDWARDS et al., 2008). In histopathology examinations, bacteria of the Sarcina genus were observed on the surface but not within the abomasal wall, similar to other reports in the literature (VATN et al., 2000). In this report the diagnosis was based on morphological findings, and was not carried out the bacterial isolation. In previous studies in animals and humans the histology and cytology methods have been often used because bacteria of Sarcina genus have an unique morphological feature that is not found in other agents, as well as its extremely difficult isolation of which in most cases revealed negative results (DEBEY et al., 1996; VATN et al., 2000; EDWARDS et al., 2008; KUMAR et al., 2014; BHAGAT et al., 2015; SOPHA et al., 2015). In a previous study, 67 lambs with abomasal disease (abomasal bloat or rupture) and 45 healthy lambs were analyzed histopathologically, and the study found bacteria of the Sarcina genus in the abomasum of 53 lambs with abomasal disease and the absence of this bacteria in the abomasum of healthy lambs, demonstrating a possible causal association between bacteria from the Sarcina genus and gas accumulation in the abomasum. From just only one of these lambs the Sarcina bacteria was isolated; therefore they concluded that the evaluation of smears in combination with histopathology of the abomasum was a strongly suggestive diagnostic method (VATN et al., 2000), as done in this report. Morphologically, the main differential diagnosis in this case is bacteria of the Micrococcus genus; however, these are smaller $(0.5 \mu \mathrm{m})$ and tend to form agglomerates, a feature not described within bacteria of the Sarcina genus (LAM-HIMLIN et al., 2011).

In the outbreak described here, the introduction of protein salt associated with the primary diet of the lambs created a highly fermentable substrate, predisposing to bacterial multiplication, which culminated in the development 


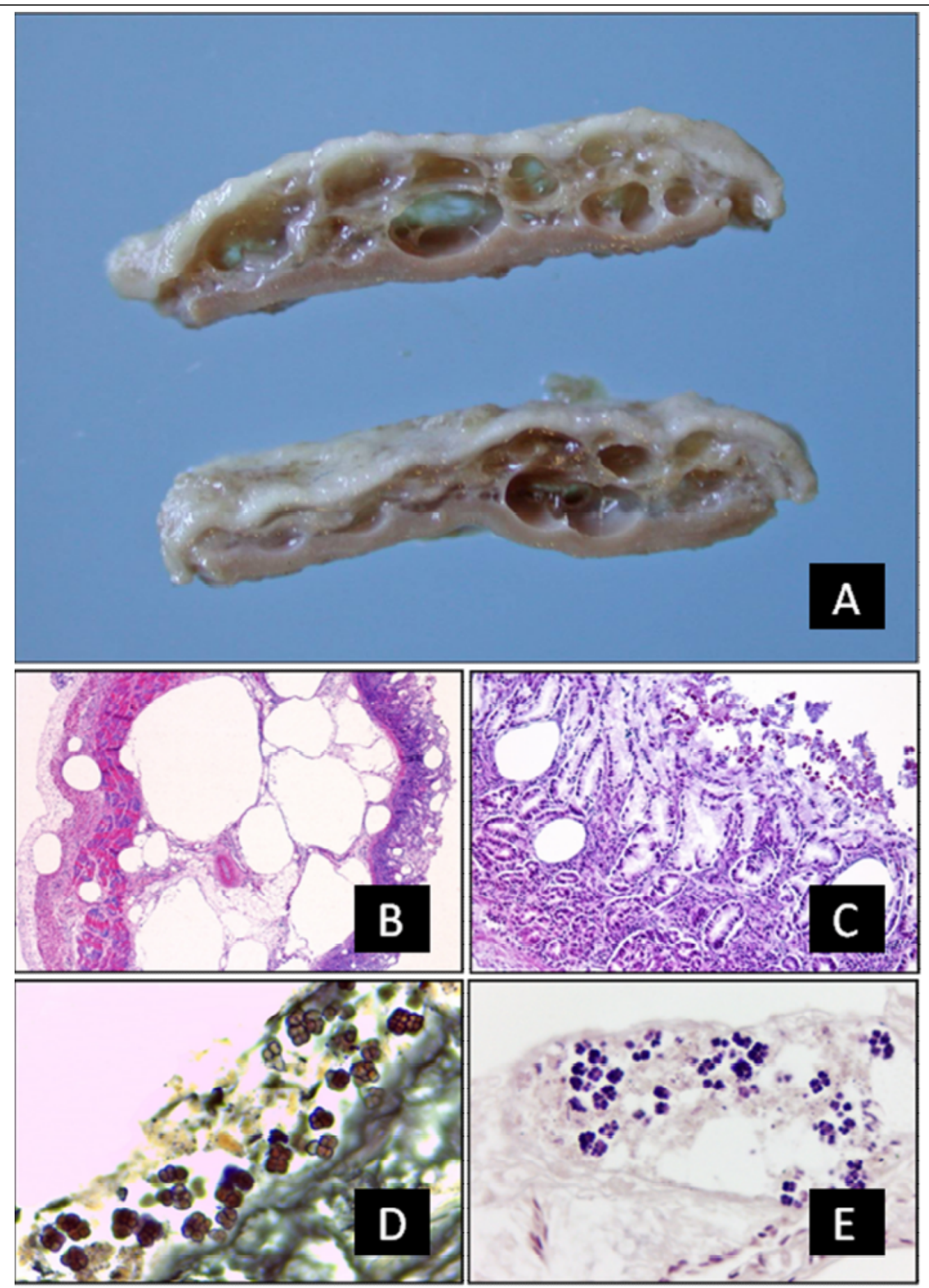

Figure 1 - Lamb. Emphysematous abomasitis. A. The abomasum with a thickened wall distended by gas and with an emphysematous aspect. B. Marked diffuse emphysema in the submucosa and mild multifocal emphysema in the mucosal, muscular and serosal layer. HE, 400x. C. Mild superficial necrosis with numerous small coccoid structures approximately $2 \mu \mathrm{m}$ in diameter. HE, 200x. D. Illustration of bacteria by Grocott's methenamine silver stain, 400x. E. Illustration of bacteria stained blue (Grampositive) by the modified Brown-Hopps (Gram) technique, 400x. 
of the emphysematous abomasitis observed in the necropsied animals and possibly caused the additional deaths. In addition, the ingestion of food contaminated by bacteria of the Sarcina genus by young ruminants results in excessive gas production and fermentation as described by EDWARDS et al. (2008), creating an anaerobic environment that promotes bacterial multiplication. This was also described by PANCIERA et al. (2007) during abomasal bloat in young ruminants fed with an ad libitum feeding system that resulted in the consumption of great quantities of fermentable foods. The presence of the bacteria associated with bloat, emphysema and abomasal mucosal injury is similar to previous reports (DEBEY et al., 1996; VATN et al., 2000; VAALA \& HOUSE, 2002; PANCIERA et al., 2007; EDWARDS et al., 2008).

Prevention of this syndrome does not require therapeutic or prophylactic medication and can be accomplished through dietary management (PANCIERA et al., 2007), such as the removal of the protein salt in this study, which ended the deaths. In this case, bacterial culture was not performed because initially, based on the gross findings, there was no other bacterial disease as a differential diagnosis. Therefore, the diagnosis of this outbreak was established based on the gross and microscopic findings observed in the abomasum of a necropsied lamb, associated with the clinical and epidemiological information from other affected animals. Histopathology was a reliable, simple and effective method for the diagnosis of emphysematous abomasitis caused by the Sarcina genus of bacteria because these bacteria have a unique morphology, making it possible to distinguish them from other etiologic agents. Additional studies are essential to clarify the predisposing factors and the interrelations between the clinical, pathological, and etiological factors of this condition.

\section{REFERENCES}

CANALE-PAROLA, E. Biology of the sugar-fermenting Sarcinae. Bacteriolgy Reviews, v.34, p.82-97, 1970. Available from: <file://D:/LBMA_docs/Downloads/bactrev00070-0090. pdf2>. Accessed: Jan. 19, 2015.
BHAGAT, P. et al. A rare association of Sarcina with gastric adenocarcinoma diagnosed on fine-needle aspiration. Journal of Cytology, v.32, p.50-52, 2015. Available from: <http://www.jcytol. org>. Accessed: Jul. 26, 2015. doi: 10.4103/0970-9371.155238.

DEBEY, B.M., et al. Abomasal bloat associated with Sarcinalike bacteria in goat kids. Journal of the American Veterinary Medical Association, v.209, p.1468-1469, 1996.

EDWARDS, G.T. et al. Sarcina-like bacteria associated with bloat in young lambs and calves. Veterinary Record, v.27, p.391-393, 2008. Available from: $<$ http://veterinaryrecord.bmj.com/content/163/13/391. long>. Accessed: Jan. 19, 2015. doi: 10.1136/vr.163.13.391.

GOODSIR, J. History of a case in which a fluid periodically ejected from the stomach contained vegetale organisms of an undescribed from. Edinburgh Medical and Surgical Journal, v.57, p.430443, 1842. Available from: <http://biostor.org/reference/94682>. Accessed: Jan. 19, 2015. doi: 10.1080/03745484309445276.

KUMAR, M. et al. Co-infection of Sarcina and Giardia in a child. Oxford Medical Case Report, v.7, p.118-119, 2014. Available from: <http://omcr.oxfordjournals.org/>. Accessed: Jul. 26, 2015. doi: 10.1093/omcr/omu046.

LAM-HIMLIN D. et al. Sarcina organisms in the gastrointestinal tract: a clinicopathologic and molecular study. American Journal SurgicalPathology,v.35,p.1700-1705,2011. Available from: $<$ http:// www.sciencedirect.com/science/article/pii/0167587783900041>. Accessed: Jan. 19, 2015. doi: 10.1016/0167-5877(83)90004-1.

LUTNAES, B.; SIMENSEN, E. An epidemiological study of abomasal bloat in young lambs. Preventive Veterinary Medicine, v.1, p.335-345, 1983. Available from: <http://www.ncbi.nlm.nih. gov/pmc/articles/PMC3193598>. Accessed: Jan. 19, 2015. doi: 10.1097/PAS.0b013e31822911e6.

PANCIERA, R.J. et al. Tympany, acidosis, and mural emphysema of the stomach in calves: report of cases and experimental induction. Journal Veterinary Diagnostic Investigation, v.19, p.392-395, 2007. Available from: <http://vdi.sagepub.com/content/19/4.toc $>$. Accessed: Jan. 19, 2015. doi: 10.1177/104063870701900409.

SOPHA, S.C. et al. Sarcina, a new threat in the bariatric era. Human Pathology, Jun 5, 2015. [Epub ahead of print]. Available from: <http://www.humanpathol.com/>. Accessed: Jul. 26, 2015. doi: 10.1016/j.humpath.2015.05.021.

VAALA, W.E.; HOUSE, J.K. Abomasal tympany. In: _ _ Large animal internal medicine. 3.ed. St. Louis: Mosby, 2002. p.304.

VATN, S. et al. Sarcina-like bacteria, Clostridium fallax and Clostridium sordellii in lambs with abomasal bloat, haemorrhage and ulcers. Journal of Comparative Pathology, v.122, p.193-200, 2000. Disponível em: <http://idealibrary.com>. Accessed: Jan. 19, 2015. doi: $10.1053 /$ jcpa.1999.0363. 